\title{
Factors influencing the labour market insertion of undergraduate graduates from Peruvian universities
}

\author{
Pedro Yvan Saenz Rivera ${ }^{a}$, Judith Soledad Yangali Vicente ${ }^{b}$ \\ ${ }^{a}$ Universidad Nacional Federico Villarreal, ORCID 0000-0002-8131-4997 \\ ${ }^{\mathrm{b}}$ Universidad Privada Norbert Wiener, ORCID 0000-0003-0302-5839 \\ b judith.yangali@uwiener.edu.pe
}

Article History: Received: 10 November 2020; Revised 12 January 2021 Accepted: 27 January 2021; Published online: 5 April 2021

\begin{abstract}
The objective of the research was to propose that some socio-demographic factors: gender, economic level and parents' education; basic education factors such as the department and type of secondary education management and mainly undergraduate and postgraduate factors measured by the characteristics of the university-career explain the insertion of university graduates in the Peruvian labour market. The quantitative, theoretical and explanatory approach study consisted of the analysis of information received from the Ministry of Education, a sample of 8072 graduates from 2014-2017 from a total of 15 private universities and 35 state universities. We found $50 \%$ of graduates employed with adequate hours, wages and tasks, $21 \%$ with inadequate employment and the remaining $29 \%$ unemployed. Using the multinomial logistic regression model, it was shown that engineering degrees have 4 times the employment opportunity, while graduating from a university in the first places in the Research Ranking favours employment by around 50\%, gender, department, family income and the mother's level of education are also factors that condition employment insertion.
\end{abstract}

Keywords: Labor insertion, employability, labor market, multinomial logistic regression

\section{Introduction}

The International Labour Office ILO (2020) in its report World Employment and Social Outlook: Trends 2020 indicates that there is no correspondence between labour supply and demand, factors such as geographical location and gender of a person determine their probability of finding a job, the female activity rate was only $47 \%$, below that of men with 74\%; on the other hand, age is another characteristic of inequality in the labour market, $22 \%$ of young people aged 15 to 24 years do not have a job or education. According to the International Labour Organisation (ILO, 2019) for Latin America and the Caribbean, the youth unemployment rate is three times higher than the adult unemployment rate, and those who find work do so in unfavourable conditions.

For its part in Peru, the National Institute of Statistics and Informatics, hereinafter INEI (2020b) in its technical report $\mathrm{N}^{\circ} 1$ - February 2020, indicates that at the national level during 2019 unemployment in the case of economically active women reached $4.5 \%$, exceeding that of men by one percentage point, in the case of those with a higher university level the unemployment rate reached $6.1 \%$ and although it has decreased compared to $2018(6.7 \%)$ it is much higher compared to the rest of the educational levels: primary $1.4 \%$; secondary $4.4 \%$ and higher non-university with $4.2 \%$ unemployment. As for Metropolitan Lima and Callao, according to INEI (2020a) the unemployment rate for 2019 was $6.6 \%$. In the case of women, the rate was $7.9 \%$, exceeding that of men $(5.5 \%)$. This report also indicates that the unemployment rate in the Oct-Nov-Dec quarter for people with higher education reached $7.2 \%$, exceeding as in other years the unemployment rates of the other categories of educational attainment.

According to the National Superintendence of Education, hereinafter SUNEDU, in its latest Biennial Report on the Peruvian university reality SUNEDU (2020: 124) when analysing the unemployment rate of university graduates aged 21-35 years between the years 2012 to 2018, it is observed that the level of unemployment of graduates is always higher than that of their peers with a lower level of education, which went from $6.7 \%$ in 2012 to $8.8 \%$ in 2018, with respect to this authors such as Lavado, Martinez and Yamada (2014) argue that this is a consequence of university deregulation initiated in 1996 with the creation of the National Council for the Authorisation of University Operations, hereafter CONAFU, which brought about a decrease in the quality of higher education and contributed to professional underemployment in Peru. The conclusions of his work indicated a major growth of graduates far in excess of market demand, which is aggravated in the case of saturated careers and with every four out of ten university professionals in 2012 in a situation of overeducated, occupying nonprofessional and underpaid vacancies, at the same time in the case of graduates of "lower quality" universities, the 
probability of being underemployed increased from 0.19 to 0.30 from the opening and deregulation of the Peruvian university market.

Therefore, it is justified to know the real demand for professionals in Peru and to monitor graduates with special interest in the characteristics of their labour market insertion, so that policies can be generated to support an adequate transition from university to employment, as mentioned by Barragan and Espuna (2019), the interest groups associated with university education demand quality products and services that contribute to the economic development of countries and also access to opportunities in the labour market that guarantee the professional development of university graduates.

Faced with this complex panorama in the labour sector, with informality, gender gaps, underemployment, over-supply of higher education, over-education, it is worth asking what are the factors that influence the labourprofessional insertion of university graduates? SUNEDU (2018: 89) in its first biennial report points out that in addition to the university factor, there are conditions external to the university such as ethnicity, gender of the graduate, social capital, family background, which have also been shown to be determinants of labour success measured in terms of wage remuneration and formality. There are even non-cognitive skills such as entrepreneurship, self-determination and resilience, which influence the employment conditions of graduates and on which university education has less possibility of intervening.

The research is limited to the data available in the latest national survey of graduates, which does not consider all universities in Peru. The documentary review of the data provided by the Ministry of Education (MINEDU), the National Survey of University Graduates 2017, does not indicate the criteria used for the selection of the 35 public and 15 private universities, while on the other hand it does mention the randomness considered in the selection of the sampling units (careers and students).

\section{Method}

A quantitative approach was used, and it can be classified as a theoretical or basic research, with a nonexperimental design, and with an explanatory scope. The population is made up of university graduates from 2014-2017, the unit of analysis was the university graduate and the observations were provided by MINEDU through a sample of 10801 graduates between 2014 and 2017 whose survey was extended until 2018, after reviewing the consistency of the raw data, 8072 graduates from 2014-2017 were considered for the analysis, whose coverage reaches a total of 15 private universities and 35 state universities in Peru.

The 2017 National survey of students and graduates conducted by MINEDU was a probabilistic, list-based, stratified, two-stage and independent survey in each university, using the information provided by the universities as a sampling frame, the technique used was the face-to-face survey and the information was collected on a structured questionnaire of 199 questions distributed in VII chapters directly on a Tablet.

On the basis of a documentary observation, some conditioning elements of labour market insertion were proposed, considering socio-demographic factors such as gender, age and academic level of the graduate's parents, family income and the employment situation of the family circle or close friends; factors of basic secondary education such as the geographical location and type of management of the institution (public or private); and finally the educational factors of undergraduate and postgraduate education, consisting of the main characteristics of the educational institution and some events related to university life, also including the final perceptions of the graduate about his or her place of study.

In the first part of the analysis, taking as a reference the methodology indicated in INEI (2020b), we proceeded to classify the graduates into 3 excluding categories of labour market insertion: Unemployed, adequately employed and inadequately employed.

(i) Unemployed: if at the time of the survey they stated that they did not have a current job; Employed: those who stated that they had a current occupation or job, these in turn were classified as adequately employed or inadequately employed.

(ii) Adequately employed: Any employed graduate in whom the following conditions were simultaneously verified:

a. Their occupation must be related to the graduate's career.

b. If he/she is a dependent employee, he/she must have a formal contract with his/her employers.

c. If you are self-employed you must be declaring to SUNAT.

d. Have a remuneration higher than the minimum living wage.

e. Work at least 35 hours a week.

f. If working less than 35 hours you must indicate that you do not wish to work more hours. 
(iii) Inadequately employed: A graduate with a current occupation but who is not classified as adequately employed.

\section{Factors conditioning labour market insertion}

Many of the factors taken into account were supported by the review of various research papers, sociodemographic factors such as the level of education of parents was supported by Bedoya, Lopez \& Marulanda (2019) in their scientific-technological article indicated that young people with mothers with higher levels of schooling take less time to get a job compared to graduates whose parents did not study or did not finish primary school, In addition, they concluded that the factors that significantly predict the time it takes to find the first job, as for the sex of the graduate, several studies indicate that it is a prevalent factor, we have Félix-Verduzco and Inzunza-Mejía (2019) who analysed the differences in labour participation between men and women, showing that the labour participation of women increases with educational training, especially when they reach a degree or postgraduate studies, decreasing the gender gaps but still with a minimal advantage for men; The study shows that women's participation in the labour market increases with educational attainment, especially when they attain a bachelor's degree or postgraduate studies, narrowing gender gaps but still with a minimal advantage for men.

Studies by Zwerg-Villegas \& Jiménez (2015) showed that after surveying 98 deans of management faculties of public and private universities in Colombia, there is a perception of a serious scenario of injustice and inequity in the workplace, class discrimination is identified as a notable issue and comparable to other forms of exclusion and discrimination, Vizcardo (2018) presented the results of his doctoral thesis, which indicates that in the case of graduates of the professional school of Administration of the National University of San Agustín in Peru, age and marital status is an important factor when it comes to finding a job. In addition, basic education factors such as the department of the school or its management type were considered, since these variables could contain information about the characteristics of the graduate, such as place of birth and socio-economic status.

\section{Teorías sobre la relación entre educación y trabajo}

In his doctoral thesis, Carrasco (2019) studies indicate that graduates of dentistry programmes from accredited universities worked fewer hours compared to graduates from non-accredited universities; Sánchez (2019) shows that the quality of the university of graduation, the degree and gender, among other factors, are associated with employability; Lavado et al. (2014) show that underemployment is related to graduating from "lower quality" universities and also Yamada, Lavado \& Oviedo (2016) conclude that graduating from a higher quality university increases the net return of the combination career and institution by $17.3 \%$ and $60 \%$ of the wage differences are explained by other socio-economic factors.

Due to the linkage of these two social domains education and work, many theories have emerged over time that attempt to explain this relationship in various fields of human knowledge. According to the human capital theory (HCT) there is a direct relationship between investment in education and economic performance. At the individual level it would be reflected in an increase in productive capacities and also in an increase in remuneration. At the collective level it would translate into an increase in productivity, so that countries that invest more in education would expect a significant increase in their overall income. According to NavarroCendejas (2013) the principle of this theory is that education is not only a consumer good but primarily a profitable investment and therefore acquires the same properties as a physical or financial investment and for this reason people who invest in education will have as a result a "human" capital. He further states that each individual could know the expected return on an investment in education and thus could become a "capitalist" who invests in himself.

On the other hand, the adaptationist theory or approach, also called "correspondence perspective", according to Navarro-Cendejas (2013) "is based on two basic principles: 1) Each level and speciality is related to a restricted set of labour categories and 2) This correspondence constitutes the optimal form of exchanges in the labour market" (p.51). ), in the same vein Navarro-Cendejas (2013) and Hernández (2019) agree in affirming that, in accordance with HCT, the adaptationist theory shares some of the main aspects of this theory, as it rigidly associates the results of educational graduates with a set of specific jobs in the labour market.

This theory assumes that there is a perfect correspondence between the actors, i.e. the adaptationist approach states that if the graduate received a quality education, this will be reflected in the way he/she enters the labour market with a job in line with his/her professional training, however, as the detractor theories argue, this does not always end up being a reality in the contemporary world. Another theory related to these concepts is credentialism, which was developed by sociologist Randall Collins in his 1979 work "The Credentialist Society", Collins (1979) argues that educational credentials (university degrees) become a decisive factor in justifying access to employment and privileged social positions, In order to evaluate candidates, employers are forced to resort to the only productivity indicators to which they have access, "credentials", which in reality do not 
guarantee productivity because there is political and social work to influence the perception of certain jobs, but nevertheless credentials do allow a selection of those who can be trained in the company.

Finally, we have the theory of the competence-based approach, the term "competence" was developed by David McClelland in 1973, as an approach opposed to the traditional measures used to predict or explain job performance. Competences have various conceptualisations, it is a polysemous term and its categorisation is broad, the best known and which could standardise all existing ones is the ILO's categorisation (2003) which classifies three types of competences; basic, specific and generic. A variety of this concept are the professional competences which, by focusing on their characteristics and potential in the labour framework, can be defined as the capacities, skills and attitudes of specialisation that a subject possesses for the development of a certain activity referring to the professional field; these are acquired through higher education and are valued in the labour market and positively affect the labour insertion of the individuals who possess them (Pelayo, 2012).

According to Navarro-Cendejas (2013), this theory mainly criticises the adaptationist approach, and argues that access to different levels of training by society does not necessarily respond to the logic of labour demand in terms of professional qualifications; In this sense, Hernández (2019) states that the relationship between education and work must be "rethought", as it is very minimalist to continue to see it as it was in the 1960s, due to the fact that today's university graduates are inserted in a different way than those of more than half a cycle ago; the needs have changed, it is no longer enough just to have a university degree to ensure a favourable entry into the labour market. However, as Romero et al. (2004) add, professional competences are an important factor that facilitates the inclusion of professionals in the labour market, but the acquisition and use of these competences alone do not guarantee effective labour market insertion, since this also takes place on the basis of other factors such as academic training, previous work experience, insertion skills and job search methods, all of which play the role of facilitators of labour market insertion.

\section{Labour market insertion, employability and on education}

For Navarro-Cendejas (2013), labour market entry has been understood and defined in the literature as a moment or as a process. As a vital moment, it refers to the first job that a person has, while the concept of a long and gradual process refers to a period of time in which the individual manages to establish him/herself firmly within the labour market. For Romero et al., (2004) cited in Pelayo (2012), labour integration is a process that takes place when two factors that he recognises as employability and employability interact or adjust until inclusion in a vacancy is generated; this event occurs according to employability indicators (importance and interest in working, self-esteem, skills, social factors) and the disposition of the aspects encompassed by employability (market trends, demand and supply of employment, economic and demographic indicators).

With regard to employability, the dictionary of the Royal Spanish Academy (RAE, 2019) defines it as "the set of skills and attitudes that enable a person to get and keep a job". The term comes from a translation of the English word employability composed of the concepts of employment and ability. In turn, Orgemer (2002, p. 65) cited by Pelayo (2012) defines employability as "the worker's opportunity to access a job that meets their expectations, their training and their career path", while for Pelayo (2012) employability is the probability of finding a job given the characteristics of the applicants for the vacant position, and also refers to the term occupability, which is focused on the context and indicates that this refers to the possibility of finding a job, but depending on the opportunities in the world of work, while employability is only focused on the person and their learning.

Overeducation is another concept involved in this study, which was named by Freeman in 1976 as overeducation. This approach attempts to measure the mismatch between the qualification inherent in the job and the qualification of the person who performs it, following this line Marquez and Gil-Hernández (2015) define overeducation as a nominal measure of the disparity between the education acquired by the worker and his or her occupation. In both cases, the principle of this phenomenon considers that each occupation only corresponds to a certain type of skills, and hence the degree of adjustment or mismatch of individuals can be quantified according to the education acquired and the characteristics of the work performed. Wiener (2018) mentions that the problem of mismatch between the education system and the labour market as a result of the expansion of higher education has not been evident exclusively in South American countries such as Peru; European countries, such as Spain, are also witnessing an increase in the number of university graduates who do not manage to insert themselves favourably into the labour market. However, there are difficulties in determining the existence of overeducation and also the interpretation given to it, as some theories consider that this phenomenon may be a passing aspect that most people go through in the search for job stability, while other theories indicate that it may be considered a structural problem of an entire nation that impedes its development. A concept that coincides with the condition of overeducation is underemployment, which for Vedder, Matgouranis, et al. (2010) cited in Lavado, Martinez and Yamada (2014) is defined as "the condition whereby an individual fills job vacancies that have predominantly been filled by those with relatively lower levels of educational attainment, i.e. fewer years of education". 


\section{Results.}

After categorising labour market insertion using the criteria defined in the previous sections, the following results can be shown.

Figure 1: Distribution of undergraduate university graduates in Peru.

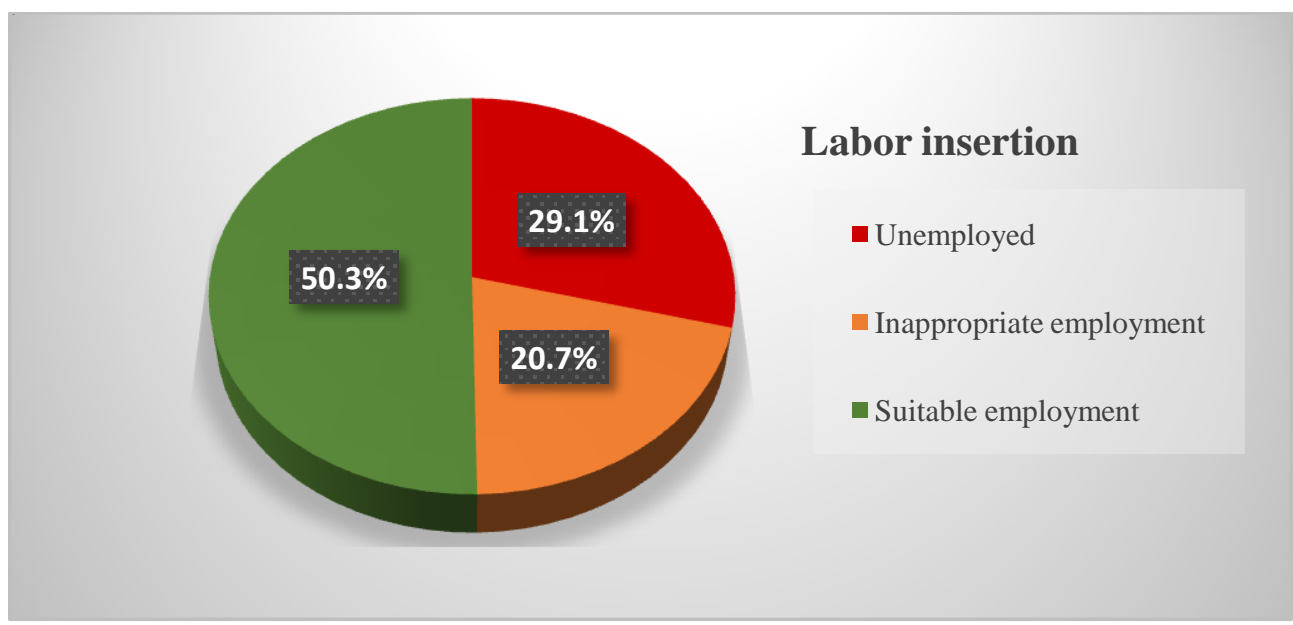

\section{Source: Own elaboration.}

Figure 01 shows that only $50.3 \%(n=4059)$ of the undergraduate graduates are adequately employed; $20.7 \%$ $(n=1668)$ are inadequately employed and 29.1\% (4059) are unemployed. In order to test the hypotheses that factors influence labour market insertion, an attempt will be made to fit the data to a multinomial logistic regression model, hereafter MRLM, which is summarised as follows: Considering 3 levels or categories for the dependent variable Labour market insertion, these categories are: $\mathrm{Y}=1$ (Unemployed); $\mathrm{Y}=2$ (Inadequately employed) and $\mathrm{Y}=3$ (Adequately employed).

Each with probabilities of occurrence:

$p_{1}, p_{2} y p_{3}=1-p_{1}-p_{2}$

Respectively, under this approach our model is:

Model: $\left\{\begin{array}{l}\ln \left(\frac{p_{1}}{p_{3}}\right)=\beta_{01}+\beta_{11}\left(X_{1}\right)+\beta_{21}\left(X_{2}\right)+\beta_{31}\left(X_{3}\right)+\cdots \beta_{n 1}\left(X_{n}\right) \\ \ln \left(\frac{p_{2}}{p_{3}}\right)=\beta_{02}+\beta_{12}\left(X_{1}\right)+\beta_{22}\left(X_{2}\right)+\beta_{32}\left(X_{3}\right)+\cdots \beta_{n 2}\left(X_{n}\right)\end{array}\right.$

Where the $\mathrm{X} \_\mathrm{i}$ represent the independent variables (factors) and for the simultaneous estimation of the parameters $\beta_{-}$ij and validation the statistical programme SPSS Version 25 was used.

Table 1 presents a summary of the maximum likelihood estimates of the MRLM for unemployment opportunities or ratios to suitable employment. First of all, we observe that the male sex has a coefficient of $\beta_{i j}=$ -0.179 significant (Sig. $<0,05$ ) this translates into a $O R=e^{-0,1179}=0,836<1$; which means that if the graduate is male the reason (or opportunity) for being unemployed is multiplied by 0,836 respecto de estar empleado de manera adecuada; dicho de otra manera $\left(O R=e^{0,1179}=1.1251\right)$ lMen have a $13 \%$ higher chance of being adequately employed compared to women in the situation of being unemployed. On the other hand, the possession of a university degree in the first years of graduation also gives an advantage in terms of adequate employability $\left(O R=e^{0,320}=1.377\right)$ versus those who do not yet have it.

Table 1: Parameter estimates of MRLM dependent category unemployed, reference category suitable employment.

\begin{tabular}{|c|c|c|c|c|c|c|}
\hline Variable & & $\mathrm{B}$ & Sig. & $\operatorname{Exp}(B)$ & $\begin{array}{l}\text { Lower } \\
\text { limit }\end{array}$ & Upper limit \\
\hline Intersection & & 2,052 & 0,000 & & & \\
\hline Gender & & $-0,179$ & 0,004 & 0,836 & 0,740 & 0,945 \\
\hline Professional title & & $-0,320$ & 0,000 & 0,726 & 0,629 & 0,839 \\
\hline \multirow{2}{*}{ Career } & Sanitary Engineering & $-1,431$ & 0,001 & 0,239 & 0,103 & 0,555 \\
\hline & Animal Husbandry & $-1,187$ & 0,001 & 0,305 & 0,147 & 0,635 \\
\hline
\end{tabular}




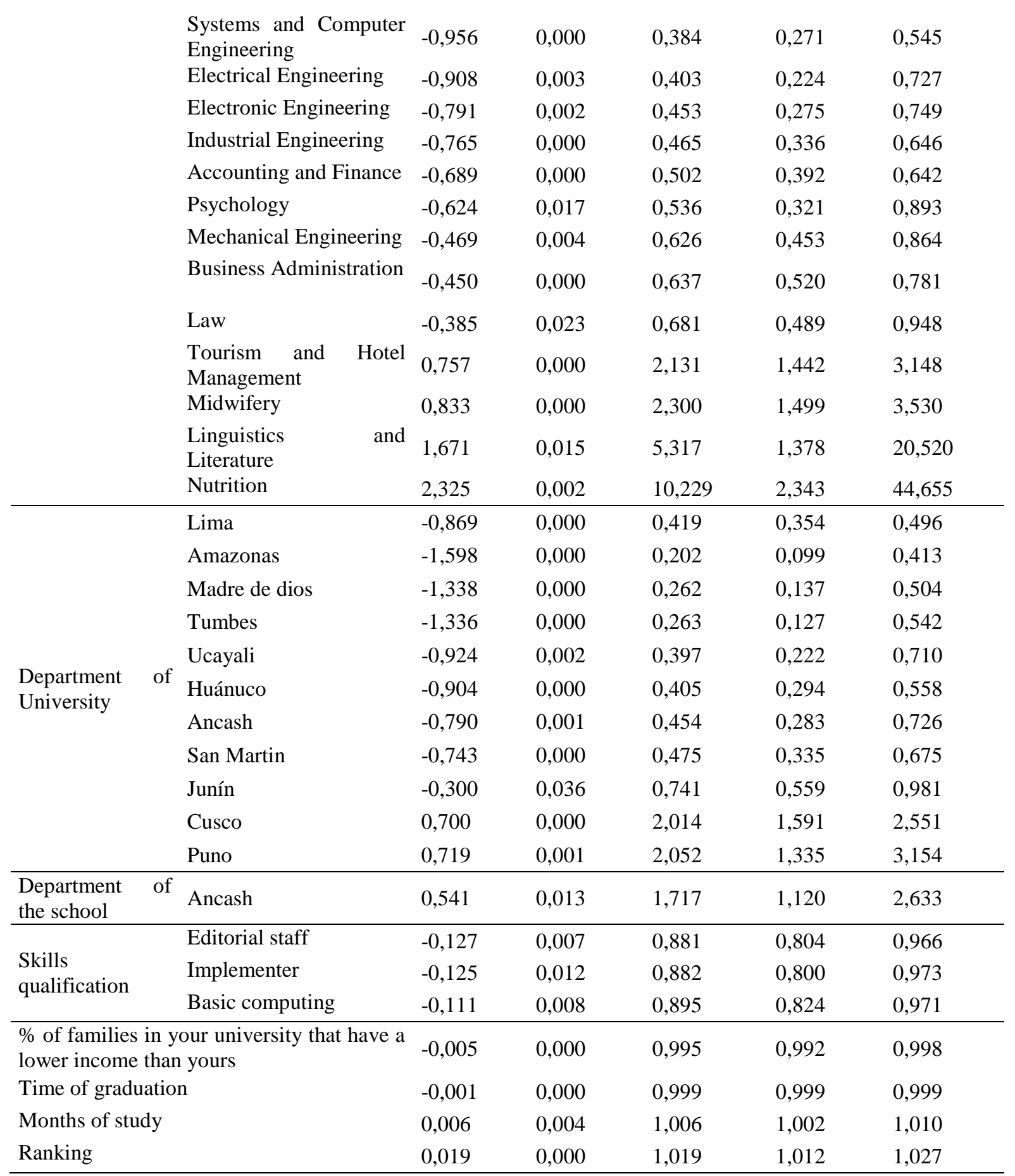

Source: Own elaboration using SPSS version 25.

With respect to the careers in the table they are ordered from lowest to highest, in this case given that the reference category is adequate employment, the more negative the value of the $\beta_{i j}$ estimated on OR will be smaller, i.e. the smaller is the ratio (or "probability") of being unemployed, in the case of engineering, the lowest RO (Industrial Engineering) is of $e^{-0.765}=0,465$ which translates into a decrease of $53,5 \%(1-0,465)$ In other words, an engineering graduate has twice the chance of being adequately employed compared to the overall average of the other degrees, even up to a 4 -fold increase $\left(O R_{\text {Ing. Sanitaria }}=e^{1,431}=4,18\right)$.

In contrast, the results indicate that graduates of the Tourism Administration, Hotel and Catering, Midwifery, Linguistics, Literature and Nutrition degrees increase the reason or opportunity to be unemployed, as shown in the columnOR $=\operatorname{Exp}(B)$ These are even doubled in the case of nutrition. Regarding the department of graduation: Lima, Amazonas, Madre de Dios, Tumbes, Ucayali, Huánuco, Ancash, San Martin also show negative coefficients with OR less than 0.5, i.e. more than twice the chance of being adequately employed than being unemployed. The opposite situation occurs in Cusco or Puno, with positive B coefficients and where the ORs 
exceed two units, which indicates that for the graduates of these departments the reason or opportunity to be unemployed is doubled; this is repeated for the graduates of secondary schools in the department of Ancash.

Regarding Skills acquired at University (self-perception), writing, implementation skills and basic computer skills are advantageous, e.g. having basic computer skills reduces the probability of being unemployed by $10.5 \%$ (1- 0.895). And with respect to family income measured in relative terms on a scale from 0 to 100 , where 0 indicates high income and 100 indicates very low income, for each point the reason for being unemployed is multiplied by 0.995 ; in other words, if we consider the change in opportunity from a graduate with very low family income to one with high income, for example, a difference of 85 points would be equivalent to an increase by 1.5 in the opportunity of being employed $O R_{85}=e^{0,005(85)}=1,52$.

The variable Rankin of the university (Ranking in the research aspect, First place $=1$, last place $=33$ ) presents an OR of 1.019; which indicates how the chance of being unemployed increases as one occupies lower places. If we consider the last place in the ranking (33rd place) we would be $O R_{33}=e^{0,019(33)}=1,019^{(33)}=1$,88; i.e. almost double the chance of being unemployed.

Table 2 presents a summary of the MRLM's maximum likelihood estimates but now for the opportunities or reasons for inadequate employment relative to adequate employment. First of all, we observe that graduates from private universities in corporate administrative management have a OR de 0,609 which indicates that the reason or opportunity for being inappropriately employed decreases by a 39,1\% in favour of being properly employed.

Table 2: Estimated MRLM dependent category inadequately employed, reference category adequately employed parte I

\begin{tabular}{|c|c|c|c|c|c|c|}
\hline \multicolumn{2}{|c|}{ Variable } & $\mathrm{B}$ & Sig. & $\operatorname{Exp}(B)$ & $\begin{array}{l}\text { Lower } \\
\text { limit }\end{array}$ & Upper limit \\
\hline \multicolumn{2}{|c|}{ Intersection } & 0,322 & 0,373 & & & \\
\hline \multicolumn{2}{|c|}{ Corporate Governance } & $-0,496$ & 0,001 & 0,609 & 0,459 & 0,808 \\
\hline \multirow{17}{*}{ Career } & Health Engineering & $-2,233$ & 0,002 & 0,107 & 0,025 & 0,453 \\
\hline & Pharmacy and Biochemistry & $-1,994$ & 0,007 & 0,136 & 0,032 & 0,572 \\
\hline & Chemistry & $-1,529$ & 0,001 & 0,217 & 0,086 & 0,546 \\
\hline & Electrical Engineering & $-1,184$ & 0,002 & 0,306 & 0,143 & 0,654 \\
\hline & Industrial Engineering & $-1,057$ & 0,000 & 0,347 & 0,218 & 0,553 \\
\hline & $\begin{array}{l}\text { Systems and Computer } \\
\text { Engineering }\end{array}$ & $-0,803$ & 0,000 & 0,448 & 0,305 & 0,658 \\
\hline & Mechanical Engineering & $-0,744$ & 0,000 & 0,475 & 0,318 & 0,710 \\
\hline & $\begin{array}{l}\text { Mining, Metallurgical and } \\
\text { Petroleum Engineering }\end{array}$ & $-0,712$ & 0,001 & 0,490 & 0,317 & 0,759 \\
\hline & Electronic Engineering & $-0,602$ & 0,035 & 0,548 & 0,313 & 0,959 \\
\hline & Accounting and Finance & $-0,447$ & 0,001 & 0,640 & 0,487 & 0,839 \\
\hline & Business Administration & $-0,428$ & 0,000 & 0,652 & 0,514 & 0,827 \\
\hline & Psychology & 0,612 & 0,005 & 1,843 & 1,206 & 2,817 \\
\hline & Communication Sciences & 0,634 & 0,004 & 1,884 & 1,231 & 2,883 \\
\hline & Secondary Education & 0,668 & 0,003 & 1,950 & 1,260 & 3,019 \\
\hline & Dentistry & 0,839 & 0,001 & 2,314 & 1,431 & 3,741 \\
\hline & Primary Education & 0,852 & 0,002 & 2,344 & 1,350 & 4,068 \\
\hline & Early Childhood Education & 1,059 & 0,000 & 2,882 & 1,746 & 4,757 \\
\hline
\end{tabular}




\begin{tabular}{|c|c|c|c|c|c|}
\hline Veterinary & 1,121 & 0,000 & 3,069 & 1,764 & 5,340 \\
\hline Medical Technology & 1,167 & 0,001 & 3,212 & 1,651 & 6,248 \\
\hline Other Education Careers & 1,526 & 0,004 & 4,600 & 1,646 & 12,860 \\
\hline $\begin{array}{l}\text { Anthropology and } \\
\text { Archaeology }\end{array}$ & 1,787 & 0,000 & 5,973 & 2,303 & 15,491 \\
\hline Nutrition & 1,915 & 0,018 & 6,784 & 1,383 & 33,271 \\
\hline Physical Education & 1,917 & 0,000 & 6,800 & 2,594 & 17,829 \\
\hline $\begin{array}{l}\text { Tourism and Hotel } \\
\text { Management }\end{array}$ & 2,043 & 0,000 & 7,716 & 5,359 & 11,111 \\
\hline
\end{tabular}

Source: Own elaboration using SPSS version 25.

Table 3: Estimated MRLM dependent category inadequately employed, reference category adequately employed parte II

\begin{tabular}{|c|c|c|c|c|c|c|}
\hline Variable & & B & Sig. & $\operatorname{Exp}(B)$ & $\begin{array}{l}\text { Límite } \\
\text { inferior }\end{array}$ & $\begin{array}{l}\text { Límite } \\
\text { superior }\end{array}$ \\
\hline \multirow{10}{*}{$\begin{array}{l}\text { Department } \\
\text { University }\end{array}$} & Lima & $-0,893$ & 0,000 & 0,409 & 0,338 & 0,495 \\
\hline & Madre De Dios & $-1,423$ & 0,000 & 0,241 & 0,121 & 0,479 \\
\hline & Cerro Pasco & $-0,978$ & 0,000 & 0,376 & 0,241 & 0,588 \\
\hline & Ucayali & $-0,897$ & 0,003 & 0,408 & 0,226 & 0,734 \\
\hline & San Martín & $-0,640$ & 0,001 & 0,527 & 0,363 & 0,766 \\
\hline & Cajamarca & $-0,613$ & 0,003 & 0,542 & 0,359 & 0,817 \\
\hline & Amazonas & $-0,579$ & 0,038 & 0,561 & 0,324 & 0,969 \\
\hline & Junín & $-0,527$ & 0,002 & 0,590 & 0,421 & 0,827 \\
\hline & Huánuco & $-0,405$ & 0,010 & 0,667 & 0,490 & 0,909 \\
\hline & Puno & 0,778 & 0,001 & 2,176 & 1,378 & 3,438 \\
\hline \multirow{2}{*}{$\begin{array}{l}\text { Department of } \\
\text { the school }\end{array}$} & Ica & $-1,137$ & 0,038 & 0,321 & 0,110 & 0,937 \\
\hline & Moquegua & 0,832 & 0,049 & 2,299 & 1,004 & 5,265 \\
\hline \multicolumn{2}{|l|}{ Ranking } & 0,027 & 0,000 & 1,028 & 1,019 & 1,037 \\
\hline \multicolumn{2}{|l|}{ Months of study } & 0,009 & 0,000 & 1,009 & 1,005 & 1,014 \\
\hline \multicolumn{2}{|l|}{ Time of graduation } & $-0,001$ & 0,000 & 0,999 & 0,999 & 0,999 \\
\hline \multicolumn{2}{|c|}{ Academic level achieved mother } & $-0,077$ & 0,009 & 0,926 & 0,874 & 0,981 \\
\hline \multirow{2}{*}{$\begin{array}{l}\text { Qualification of } \\
\text { the new graduate } \\
\text { in Skills }\end{array}$} & Editorial staff & $-0,125$ & 0,017 & 0,883 & 0,796 & 0,978 \\
\hline & Financial & $-0,117$ & 0,018 & 0,890 & 0,807 & 0,980 \\
\hline
\end{tabular}

Source: Own elaboration using SPSS version 25.

The careers with a negative Beta parameter, or OR less than unity, correspond to graduates whose chances of being inadequately employed are lower than the rest $\mathrm{OR}=\mathrm{EXP}(\mathrm{B})=0,107$, or $O R_{\text {Ing. Sanitaria }}=e^{2,233}=9,32$ i.e. it increases by up to 9 times the reason or advantage of being adequately employed over being inadequately employed. This is followed by Pharmacy and Biochemistry, Chemistry, Electrical Engineering, Industrial Engineering, Systems and Computer Engineering, Mechanical Engineering, Mining Engineering, Metallurgy and 
Petroleum Engineering OR is less than 0,5; i.e. more than twice as much opportunity for suitable employment than unsuitable employment.

The careers with a positive B or OR > 1 correspond to careers in which the opportunity of being inadequately employed is greater than those of being adequately employed, Anthropology and Archaeology, Nutrition, Physical Education and Tourism and Hotel Management with an OR greater than 5; in other words, the reason or opportunity of being inadequately employed is more than 5 times greater than being adequately employed. With respect to the departments of the University, an important advantage is observed in Lima, Madre de Dios, Cerro Pasco and Ucayali with an $\mathrm{OR}<0.5$ and the opposite is true for Puno (OR > 1), with Puno having twice the chance of being inadequately employed.

The ratio of inadequate employment is multiplied by 1.028 for each place below the first university in the ranking. Time of graduation and months of study have a similar effect as in the case of the unemployed. If the mother increases her level of education the chance of being inadequately employed decreases in favour of adequate employability by $7.4 \%$ (1- 0.926) for each level, which means for example that the chance of a graduate of a mother with postgraduate studies will increase her ratio of achieving adequate employment by 1.587 over inadequate employment. Finally, as financial and writing skills improve, the ratio of being inadequately employed decreases.

\section{Conclusions}

The insertion into the labour market is an aspect of vital importance in society and is currently perceived as a major concern of recent graduates of Peruvian universities, official figures from INEI (2014) mention that $12.4 \%$ of graduates are unemployed, while SUNEDU (2020) states that the proportion of unemployed university graduates has risen steadily since 2014 , reaching a figure of $8.8 \%$ in 2018 , results that are congruent with those shown in this article, which estimates that $29.1 \%$ of graduates were unemployed in 2018 .

The objective of this research was to show that there are factors that condition the labour market insertion of graduates, in that line one of the first results indicates that the gender gap is maintained, men show more opportunities for suitable employment at a rate of $13 \%$, high family income improves the advantage or opportunity ratio of being adequately employed by more than 50\% compared to being unemployed, a graduate whose mother has postgraduate studies increases his opportunity by $60 \%$ of having a suitable employee over an inadequate one.

The high demand for engineering degrees, which double and even quadruple job opportunities, and the low employability of degrees such as Tourism Administration, Hotel Management and Gastronomy, Midwifery, Linguistics and Literature raise questions about the causes of this disparity. Again, university quality, which we try to approach through the research rankings, turns out to be another determinant of employability; universities in the first places offer a 50\% higher chance of being employed compared to universities with a "low research level".

The research also attempts to include some self-perceived competences of which financial and writing skills stand out and also increase the ratio of adequate versus inadequate employability. Finally, if universities with similar characteristics are compared, those located in Lima provide more employment opportunities.

\section{References}

Barragan, J. \& Espuna, T. (2019). La empleabilidad como elemento de marca en las instituciones de educación superior. Revista Daena (International Journal of Good Conscience), 14(2), 145-158.

Bedoya, O., López, M., \& Marulanda, C. (2019). Modelo predictivo para la identificación de factores socioculturales asociados al tiempo de búsqueda del primer empleo en egresados universitarios. Revista Virtual Universidad Católica del Norte, (58),3-18. ISSN: 0124-582.

Collins, R. (1979)The Credential Society: An Historical Sociology of Education and Stratification, Academic Press New York.

Carrasco, M. (2019). Acreditación de programas de odontología y empleabilidad de los egresados. Tesis de doctoral Universidad Nacional de Educación Enrique Guzmán y Valle, Lima, Perú.

Félix-Verduzco, G., \& Inzunza-Mejía, P. (2019). Persistencia de los roles de género en la participación laboral de las mujeres con estudios profesionales en México. Papeles de Población, 25(99),209-248. ISSN: 1405-7425.

Hernández, D. (2019). Del enfoque adecuacionista al enfoque basado en competencias: una mirada a la inserción al mercado laboral de los egresados de Sociología. Sociológica, 34(98), 189-219.

ILO (2020).World Employment and Social Outlook: Trends 2020 International Labour Office - Geneva.

INEI, (2020a). Situación del mercado laboral en Lima Metropolitana. Informe técnico Nº enero 2020.

INEI, (2020b). Comportamiento de los indicadores de mercado laboral a Nivel Nacional. Informe técnico $\mathrm{N}^{\circ} 1$ febrero 2020. 
Lavado, P. Martínez, J. \& Yamada, G. (2014). ¿Una promesa incumplida? La calidad de la educación superior universitaria y el subempleo profesional en el Perú. Banco Central del Perú: Working Paper Series. DT 2014021.

Marqués, P. y Gil-Hernández, C. (2015). Origen social y sobreeducación en los universitarios españoles: ¿es meritocrático el acceso a la clase de servicio?.Revista Española de Investigaciones Sociológicas, 150: 89-112. (http://dx.doi.org/10.5477/cis/reis.150.89).

Navarro-Cendejas, J. (2013).Universidad y mercado de trabajo en Cataluña: un análisis de la inserción laboral de los titulados universitarios, Tesis Doctoral Universitat Autònoma de Barcelona. Recuperado de http:// https://ddd.uab.cat/pub/tesis/2014/hdl_10803_134648/jnc1de1.pdf

OIT (2019). Panorama Laboral 2019 Lima: OIT / Oficina Regional para América Latina y el Caribe, 2019. 152 p.

OIT (2003). “Avance Conceptual y Metodológico de la formación profesional en el campo de la diversidad en el trabajo y de la certificación profesional". Oficina Internacional del Trabajo (OIT) y la Secretaría de Políticas Públicas de Empleo del Ministerio de Trabajo y Empleo (MTE), de Brasil.

Pelayo, M. (2012). Capital social y competencias profesionales: Factores condicionantes para la inserción laboral. Edición electronica, Tepic, Nayarit, México

Romero, V., Pérez, E., Vidal, S. y Juez, M. (2004). Inserción Ocupacional. Barcelona: Editorial Altamar. ISBN: 978-84-933142-8-6.

Sanchez, M. (2019). Empleo inadecuado y calidad universitaria: un análisis sobre los recién egresados en el Perú. Tesis de maestría Pontificia Universidad Católica del Perú.

SUNEDU (2018). Informe Bienal sobre la realidad universitaria peruana. Lima: Superintendencia Nacional de Educación Superior Universitaria.

SUNEDU (2020). II Informe Bienal sobre la realidad universitaria en el Perú Lima: Superintendencia Nacional de Educación Superior Universitaria.

Wiener, L. (2018). "Estado del arte: inserción laboral y empleabilidad". Novedades Académicas, documento de trabajo $\mathrm{n}^{\circ} 2$, pp. 20.

Yamada, G., Lavado, P. y Oviedo, N. (2016). La evidencia de rendimientos de la educación superior a partir de «Ponte en Carrera». Lima: Universidad del Pacífico. Centro de Investigación. Documento de Discusión DD1608. Recuperado de <http://hdl.handle.net/11354/1429>.

Zwerg-Villegas, A., \& Jiménez, C. (2015). Discriminación Socioeconómica en La Inserción Laboral de Graduados Universitarios: Percepciones de los decanos de facultades de negocios. Revista Mexicana de Investigación Educativa, 20(64),71-93. ISSN: 1405-6666.

Vizcardo, J. (2018).Factores asociados a la empleabilidad en egresados de la escuela profesional de Administración de la Universidad Nacional San Agustín - Tesis doctoral Universidad Nacional San Agustín. Arequipa 2018. 